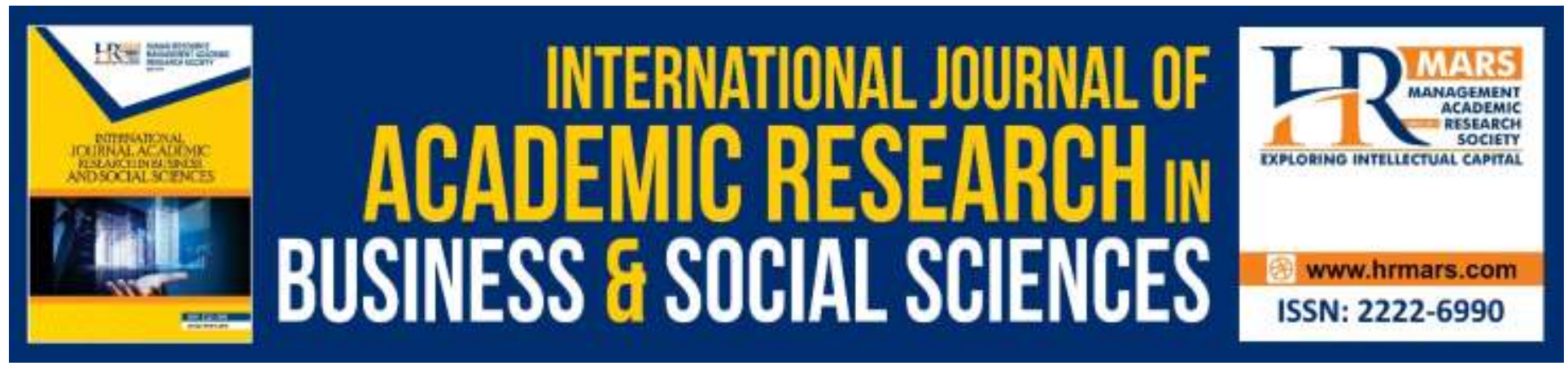

\title{
Innovativeness Orientation Behaviors and Delinquent Behavioral Change: A Case Study of Ex-Juvenile Entrepreneurial Orientation in Katsina State, Nigeria
}

\begin{abstract}
Bilyaminu Usman, Sharizal bn Hashim, Jeff Lamptey, Ashemi Baba Ali, Wasilu Suleiman, Aisha Yusuf Bilyaminu
\end{abstract}

To Link this Article: http://dx.doi.org/10.6007/IJARBSS/v10-i6/7369

DOI:10.6007/IJARBSS/v10-i6/7369

Received: 12 March 2020, Revised: 18 May 2020, Accepted: 07 June 2020

Published Online: 26 June 2020

In-Text Citation: (Usman et al., 2020)

To Cite this Article: Usman, B., Hashim, S. bn, Lamptey, J., Ali, A. B., Suleiman, W., \& Bilyaminu, A. Y. (2020). Innovativeness Orientation Behaviors and Delinquent Behavioral Change: A Case Study of Ex-Juvenile Entrepreneurial Orientation in Katsina State, Nigeria. International Journal of Academic Research in Business and Social Sciences, 10(6), 718-737.

Copyright: (c) 2020 The Author(s)

Published by Human Resource Management Academic Research Society (www.hrmars.com)

This article is published under the Creative Commons Attribution (CC BY 4.0) license. Anyone may reproduce, distribute, translate and create derivative works of this article (for both commercial and non-commercial purposes), subject to full attribution to the original publication and authors. The full terms of this license may be seen at: http://creativecommons.org/licences/by/4.0/legalcode

Vol. 10, No. 6, 2020, Pg. 718 - 737

Full Terms \& Conditions of access and use can be found at http://hrmars.com/index.php/pages/detail/publication-ethics 


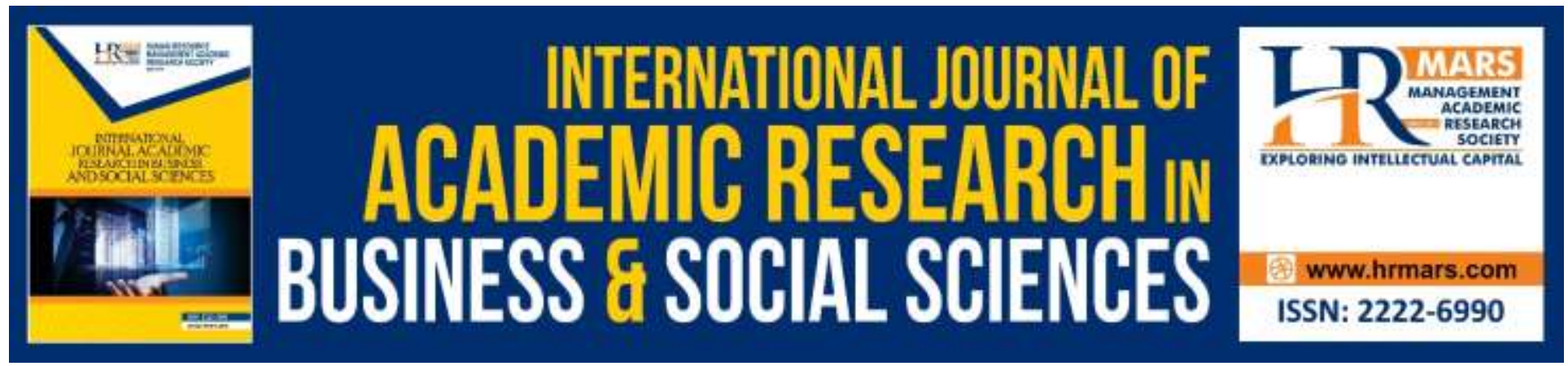

\title{
Innovativeness Orientation Behaviors and Delinquent Behavioral Change: A Case Study of Ex- Juvenile Entrepreneurial Orientation in Katsina State, Nigeria
}

\author{
Bilyaminu Usman, Sharizal bn Hashim, Jeff Lamptey \\ Faculty of Economics and Business Universiti Malaysia Sarawak. \\ Email: bilyaminu1974@gmail.com, hsharizal@unimas.my,jefflampt@gmail.com
}

\begin{abstract}
Ashemi Baba Ali
Department of Economics, University of Maiduguri, Borno State, Nigeria.

Email: ashemites@yahoo.com

Wasilu Suleiman

Department of Business Administration, Bauchi State University Gadau.

Email: wasilusuleiman@yahoo.com
\end{abstract}

\begin{abstract}
Aisha Yusuf Bilyaminu
Department of Basic and Applied Science Hassan Usman Katsina Polytechnic, Katsina State, Nigeria.

Email: aishayusufbilyaminu011@gmail.com
\end{abstract}

\begin{abstract}
Modern Entrepreneurship argument discovered the importance and the positive influence of innovativeness orientation behaviors as one of the Entrepreneurial orientations (EO) towards organizational performance and profitability. However, discussion of innovativeness orientation behaviors in the context of individuals such as entrepreneurs behavioral change influence still silent, specifically ex-juvenile entrepreneurs' context that can give an understanding into the Entrepreneurship framework of knowledge. Therefore, the purposes of the research are to understand the role of innovation orientation as one of the Individual Entrepreneurial Orientations (IEO) towards the delinquent behavioral change of ex-juvenile entrepreneurs. The study employed qualitative methods and in-depth interview to 10 research participants of exjuvenile entrepreneurs that operate entrepreneurial activities in Katsina state, Nigeria. The study used thematic analysis and NVivo 12 Pro to organize and analyze the data. The study found that
\end{abstract}


ex-juvenile entrepreneurs are innovators and more importantly innovation orientation behaviors has a positive influence on ex-juvenile entrepreneurs' delinquent behavioral change. This finding provides a fresh knowledge about the IEO innovativeness orientation potentiality in the entrepreneurs' self-development and perception into the entrepreneurship policymakers.

Keywords: Entrepreneurial Orientation, Ex-juvenile Entrepreneurs, Delinquent Behavioral Change, Innovation Orientation Behaviors, Qualitative Study, Katsina State, Nigeria.

\section{Introduction}

Entrepreneurial activities make an important contribution in the economic growth of developing countries. These activities become a source of employment and impact of economic growth (Lukes \& Laguna, 2010; Zulkifli \& Rosli, 2012). Entrepreneurship orientation (EO) is significant due to its influence on the economic development, firm's performance and profitability, social change, and job creation (Chowdhury et al., 2018; Goktan \& Gupta, 2015; Klofsten, et al., 2019). Through EO, individual entrepreneurs create value. One-way entrepreneurs create value is innovation orientation. Innovation people seek for new ideas, Experiences, and Novelty and inventive processes. Though, substantial number of the EO studies focus on firms' performance and profitability (Hughes \& Morgan, 2007; Debicki, et al., 2016) but less studies conducted on EO at individual level (Kollmann et al., 2014), particularly delinquent populace.

The scarcity of theoretical and empirical studies on individual EO is scandalous due to the assessments and natures of authors and executives form the whole strategic path of their organizations (Dickson \& Weaver, 2008). Commenting on the wildness of the EO at individual level in literature, called for more studies presenting individual EO Krauss et al., (2005). Therefore, in responding to Dickson and Weaver. Bolton, \& Lane, (2012) in their research found that, IEO resulting into three various factors that authorize the validity of innovativeness orientation, risk-taking orientation and proactiveness orientation, which consistent with entrepreneurial purposes. Consistently, (Gupta \& Gupta 2015; Wales, 2016) suggest that entrepreneurial orientation application at different levels of combination and that properly modified indicators (Miller, 2011). Nevertheless, researchers have exposed that EO dimension multidimensional could be measured together (Runyan et al., 2008; Lumpkin et al., 2009) independently (Lumpkin \& Dess, 2001; Wang, 2008), depends to the context. In this study single dimension of the IEO theory innovation dimension will be study. Therefore, Entrepreneurs appreciate innovation influence conditions and initiate developments of creative devastation that disrupt the market structures and permit new entries (Schumpeter, 1934; Witt, 2016). In this research setting, an innovative orientation behavior indicates that an individual has a positive mind-set to new ideas with regard to products and services, management, or industrial processes.

Nevertheless, some people initiate entrepreneurial own informal businesses due to the lack of other alternative which means many people in developing countries imposed to initiate and establish businesses to meet their basic need (Reynolds et al., 2002). Entrepreneurial activities offer a basis for innovation as ex-juvenile entrepreneurs innovations behaviors provide that a setting where delinquent behavioral change, security safety of the society as well as smooth integration into the society can be apprehended. The innovativeness dimension of EO theory deals with New ideas, Experiences, and Novelty and inventive processes which are part issues from existing practice and leanings related to skills (Lumpkin \& Dess, 1996). It has been 
established that innovation influence firm's performance and profitability. But there is less explanation about innovation orientation behaviors influence on ex-juvenile entrepreneurial activities and its influence towards ex-juvenile entrepreneurs' delinquent behavioral change. Therefore, in this study we are mainly interested on how IEO innovativeness orientation behaviors can influence ex-juvenile entrepreneurial activities and their subsequent influence on their delinquent behavioral change, which to the best of our knowledge never be explored, also entirely neglected ex-juvenile entrepreneur's innovation behaviors. Even though, Existing literature on delinquent's populace discovers that majority of the studies largely centered on the prison entrepreneurship programs to adult prisoners and reflected inconsistent findings (Downing 2012; Soloman, 2012; Sonfield, 2013). Henceforward, this study is worth investigation. In answer to the research gap, it is essential to investigate the innovativeness orientation behaviors of ex-juvenile entrepreneurs in Katsina state, Nigeria. The existing research tries to grow an in-depth understanding of IEO innovation orientation behaviors influence on ex-juvenile entrepreneurial activities and the innovation orientation influence towards their delinquent behavioral change in Nigeria. To answer "how is it done?" the questions could provide the sound understanding of human action or human behaviors (Munene et al., 2005). The contribution of the existing research is vast: Firstly, the finding will offer well understanding concerning exjuvenile entrepreneurial activities in Nigeria and make innovative decisions. Secondly, Fresh knowledge into individual EO, innovation orientation influence on ex-juvenile delinquent behavioral change can be resulting from this study. And thirdly, research will offer a practical solution to juvenile delinquent behaviors and have a better rehabilitation method. This will also provide a guide to some individuals, entrepreneurs and SMEs who engaged into entrepreneurial activities. Accordingly, the purposes of this study are:

$>$ To investigate innovativeness orientation behaviors, influence towards ex-juvenile entrepreneurial activities

$>$ To examine the innovativeness orientation behaviors, influence towards ex-juvenile entrepreneurs' delinquent behavioral changes.

Accordingly, the present research is organized as follows. The section 2.1 provides Ex-juvenile Entrepreneurs and Delinquent Behavioral Change. Followed by 2.2 literature and proposition development of the study. Afterward by methodology applied in the study, subsequently result and findings of the study and finally discussion, conclusion and implication of the study.

\section{Literature}

\section{Ex-juvenile Entrepreneurs and Delinquent Behavioral Change}

Ex-juvenile entrepreneurs are juvenile released from reformatory centers and currently engaging into entrepreneurial activities who creates choices and opportunities for innovation within the framework of entrepreneurship. There are prevailing frequent empirical studies on entrepreneurial autonomous in areas dealing with delinquent entrepreneurs and its impacts upon release resulted from prisons entrepreneurship programs (Sonfield, 2008; Downing, 2012; Soloman, 2012; Sonfield, 2013). Essentially, Prison Entrepreneurship Programs influence prisoners to have entrepreneurial aptitude and potentiality for entrepreneurial success (Sonfield, 2001). Furthermore, Sonfield, (2013) revealed that, $8 \%$ drop of delinquency rates also save the social order by 5 times the programs expenses. In view of the entrepreneurship' literature, exjuvenile entrepreneurs research is entirely missing or not surfacing. One of the absent literatures 
is the discussion on how autonomous influence towards ex-juvenile entrepreneur's delinquent behavioral change. Resulting in lack of significant studies conducted on ex-juvenile entrepreneurs in Katsina state, Nigeria. Therefore, this study empirically examines the influence of single IEO dimension, innovativeness orientation behaviors towards ex-juvenile entrepreneurs towards delinquent behavioral change. Bearing in mind most of the studies focused on adult prisoners none of the study pay attention on ex-juvenile entrepreneurs' surface so far, and innovativeness orientation behaviors towards ex-juvenile entrepreneur's business success and their subsequent delinquent behavioral change. Consequently, this study intends to bridge the identified gap in knowledge.

\section{Entrepreneurial Orientation Theory: Innovation Orientation and Proposition Development}

Entrepreneurship orientation is a vital organizational development that helps for interpreting managerial strategic behaviors, that empowers businesses to overwhelmed opponents by adopting innovation orientation behaviors into the business strategies to become more proactive to market prospect and risk bearing (Wiklund \& Sheperd, 2003; Jiang et al., 2016). Innovation orientation behaviors make the possibility of organizational to come up with the creativity and novelty by exploring new products and services and renewed method and system change (Dess \& Lumpkin, 2005). Experiences, new idea and inventive process is employed as a part of the contemporary practices and tendencies related to skills. (Lumpkin \& Dess, 1996; Wiklund \& Shepherd, 2005). Accordingly, if entrepreneurs have high aptitude for innovativeness orientation behaviors, they determined to attain competitive advantage and achieve better entrepreneurial performance.

Frequent researches have investigated the influence of EO and business performance and profitability with majority of these studies focused on developed nations. For instances, the literature on small and medium size firms in Spain found that influence of innovation behaviors among firms' performance are positively related (Casillas \& Moreno, 2010). Also, in Taiwan is fond positive influence on firm's performance (Wang, Chen, and Chen, 2012), in Pakistan also the same positive influence SMEs (Hameed \& Ali, 2011). It has been established that innovation orientation behaviors are serious improved firms' performance and profitability that changed influences inspire innovation among the organizations Arshad, et al., (2014). Other research also has discovered positive relationship between innovation and organizational success (Wikund \& Sheperd, 2005; Lechner \& Gudmundsson, 2014; Buli, 2017).

In Africa similar studies were also conducted. For example, in Ghana found positive relationship occur among proactiveness. Innovation and profitability Boohene et al. (2012) also in South Africa Matchaba-Hove and Vambe (2014) found innovativeness and proactiveness has positive influence on business success while risk-taking do not in slight difference, Muthee-Mwangi and Ngugi (2014) found proactiveness, risk-taking and innovation has a positive influence on MSEs growth in Kenya. Contrary, Fatoki (2014) found micro enterprises are skillfully for new products lines and product line changes, it also revealed that they are risk averse. The results also showed that Micro enterprises are less proactive and preferred to be followers rather than leaders, they are also risk averse. Despite of these studies, none have focused on single EO dimension except in Nigeria Usman, and Hashim, (2020) who explored that, autonomous orientation behaviors have a positive influence on ex-juvenile entrepreneurs' delinquent behavioral change. Still not explored ex-juvenile innovativeness orientation behaviors influence. 
Therefore, rather majority of the studies on either two dimensions or three dimensions jointly studied which make difficult to access individual finding of single EO dimension in the retail segment and still innovativeness orientation behaviors influence towards delinquent behavioral change never explored. It is established that a firm with better innovation orientation behaviors capacity in the industry will gained a better performance and profitability. (Sorescu, et al., 2003). Hence, an innovative orientation behavior is measured to have a positive influence on firm performance by take advantage of on emerging market chances (Wiklund, 1999). Considering majority, the studies focused on firm's performance as well, none of the study attempt to look into individual entrepreneurial innovativeness orientation behaviors particularly ex-juvenile entrepreneurs innovativeness orientation behaviors, despite the fact that, researchers have revealed that EO constructs multidimensional could be measured jointly (Runyan et al., 2008; Lumpkin et al., 2009) or individually (Lumpkin \& Dess, 2001; Wang, 2008), depend with the context.

In this study single dimension of the IEO theory innovation dimension will be study separately. Ex-juvenile entrepreneur's innovativeness orientation behaviors. However, quite a few above reviewed investigations have revealed negative or non-significant relationship (Andersen, 2010). Also, considering reviewed literature, the influence of innovation orientation behaviors to exjuvenile entrepreneurial activities is completely missing from the existing literature. Therefore, for the reason of these mixed finding and inconsistencies of findings, additional studies in a different setting is needed to address these inconsistencies. Therefore, the following proposition is formulated.

Propositions: Individual Entrepreneurial orientation: Innovativeness orientation behaviors influence towards ex-juvenile entrepreneurs' delinquent behavioral change.

\section{Methodology and Research Design}

The qualitative approach was employed to investigate IEO: innovation orientation dimension influence towards ex-juvenile entrepreneurs' delinquent behavioral change. This qualitative research approach is known and used in studying investors behaviors (Tijjani et al., 2009; Mohamad \& Perry, 2015). We also choose to employed qualitative research approaches because researchers use the approaches when the objective of the research is to examine human issue in the real world and reflect on the why and how the issue occurs (Yin, 2015). Qualitative methods seen as a broad group of empirical actions designed to illustrate and interpret the knowledge of research participants in a context of particular setting (Denzin \& Lincoln, 2000). Qualitative research involves human encounters regarding the quality and prospect of what the outcomes of the inquiries could indicate to the research stakeholders (Draper, 2004).

The sample from ex-juvenile entrepreneurs who retail in katsina state, Nigeria were recruited. The location was selected because the participants are residing in Katsina town and reformatory center was located close to katsina town, for easy accessibility. Purposive sampling was employed to select participants (Orobia, et al., 2013). We invited and conducted interview based on participants conveniences through formal invitation letter. Furthermore, the inclusion and exclusion criteria, for selecting participants for the study participants were selected base on those who are the residents of Katsina state and only ex-juvenile who are presently engaging into a different entrepreneurial activity, also who were detained and released from Katsina state Reformatory Centre and capable of understanding the purpose of the study. 
Nevertheless, only those who were below 18 years as at the time of admission into the Reformatory Centre, were selected even though presently they are above 18 years during the interview had also been considered. See Appendix 1 depicts the demographic profile of Research Participants study (ex-juvenile entrepreneurs). We used In-depth interview (semi-structured interviews) for data collection. In-depth interviewed involves and plan question with recognized themes in organized and constant manner, interfered with probes plan to prompt more responses elaboration (Qu \& Dumay, 2011). The focus of data collection is about the interview guide. Integrating a sequence of wide themes happen during an in-depth interview to helps in directing the interview to the main issue under investigation. In-depth (semi structured interview) is accessible, flexible, comprehensible and capable of revealing vital and unseen sides of human behaviors (Qu \& Dumay, 2011).

Correspondingly, the interviews guide was developed after a thorough review of EO theory and literature. The interview was audio recorded and transcribed verbatim. The interviews lasted for about 13 minutes to 18 minutes. According to Guest et al., (2006); Malterud, et al., (2015) six (6) to ten (10) interviews with diverse knowledge and experiences may offer sufficient data in an indepth interview, likewise, purposive sampled of 10 interviews were conducted in Katsina state, Nigeria between March, 2019 to October 2019. Interviews questions were open ended questions in nature and were design to allow the participants to express themselves in details about what the research proposed to find out in a comfortable manner McCluskey et al., (2010). Similar set of questions were presented to the participants. participants information is strictly confidential. The recorded interview was listened, transcribed in Hausa language and latter translate into English language. The thematic analysis applied and used NVivo 12 Pro computer software for organizing the data gathered.

\section{Research Design and Data Collection}

An in-depth interview was conducted to ex-juvenile entrepreneurs in Katsina state, using open questions on IEO dimensions, established and refined (adapted) by the authors. The responses were coded, categorized and organized using NVivo 12 Pro computer software. Hence data was saturated at the total of $10^{\text {th }}$ interviews were carried out to compliment the need of present research exercise as suggested by Given (2016) as saturation point. In addition, Saunders, (2018) found that five to six interviews also, Francis et al. (2010) said, in five to six interviews majority of the themes could be known. This is consistent with our own experience in the present exjuvenile entrepreneurs' study where saturation point occurred around 10 interviews. For this study, the snowball technique sampling is employed as the topic under study is sensitive and confidential in nature, ex-juvenile entrepreneurs might be unwilling to talk about their delinquents' behavior and imprisonment records, so, we reach some of the participants through the available participants friends (Loh, et al., 2011).

Regarding inclusion and exclusion criteria, the participants of the study where chooses base on those who are the residents of the Katsina state for the inclusion criteria, it was decided to involve only ex-juvenile who are presently engaging into a different entrepreneurial activity and who were detained and released from Katsina state Reformatory Centre and capable of understanding the purpose of the study. However, only those who were below 18 years as at the time of admission into the Reformatory Centre, were selected even though presently they are 
above 18 years during the interview had also been considered. See Appendix 1 depicts the demographic profile of research participants study (ex-juvenile entrepreneurs).

\section{Data Analysis Procedures}

The data were coded by using thematic analysis measures drew by Fugard, \& Potts, (2015). Thematic analysis is used for analyzing, identifying and reporting approach. Step one any factor interrelated to the knowledge of autonomous orientation and its expansion is coded. Codes can be seen as 'the main basic section, of the data that might be evaluated in an expressive means concerning the phenomena' (Boyatzis, 1998: 63). This first-order code emerged from the transcript and does not contain an explanation. Then, the first-order codes are assembled organized at abstraction construct towards content resemblances, and the procedure is recurring till a restricted figure of higher-order codes develop, that is categorized as themes. The interviews were recorded, and transliterated in Hausa Language one of the popular speaking language in West African countries particularly Nigeria, translated version of the interview into English language by research team members.

The team work together in all stages of the study, with research and technique design. Concerning coding in the following the measures (Denzin, 1989) each interview was individualistically coded by using NVivo 12 Pro computer software. Every paragraph in every interview was then discussed comprehensively purpose to explain the meaning and clarification of the autonomous experiences labeled by the informants. The process led to frequent interpretations and coding modifications and also made members conscious of expectations and biases. A procedure of theoretical coding (Guest et al., 2012) was applied to solve differences of over codes. For the purpose to remain focused on ex-juvenile entrepreneurs' innovation orientation behavior, we modified and review the earlier themes identified into the final themes for innovation and its influence. The major finding which give further clarity on the graphic interpretation of ex-juvenile entrepreneurs' innovation orientation behaviors and delinquent behavioral change in our conceptual development map in figure 1.

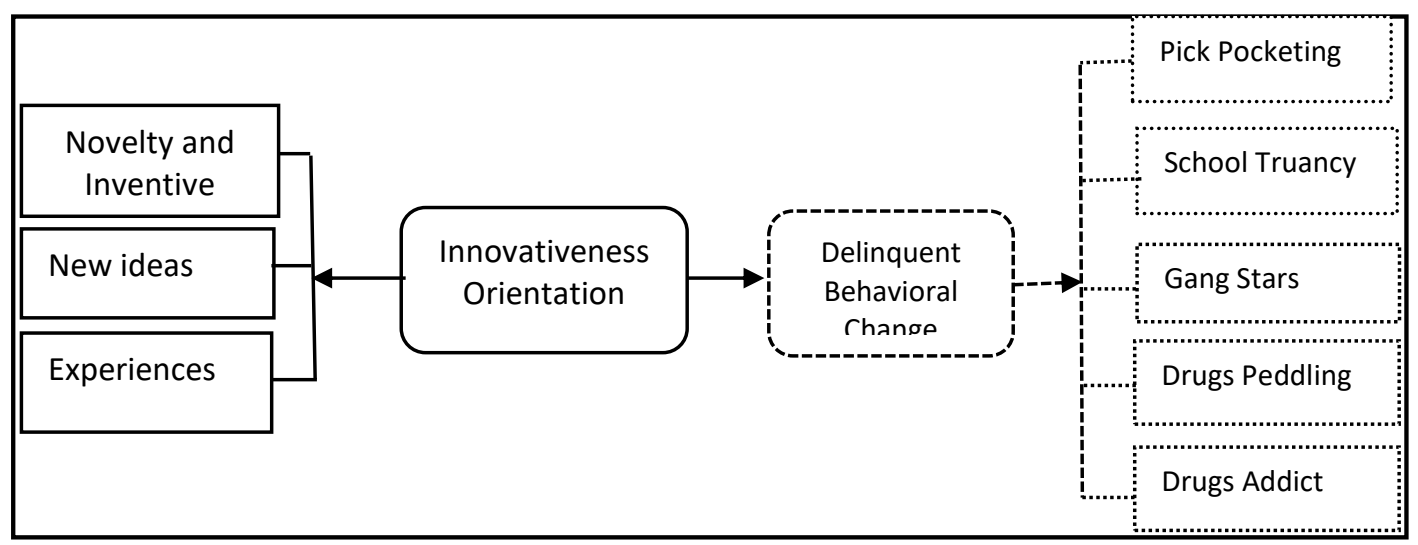

Figure 1: Concept Mapping Innovation Orientation Behavior Influence on Delinquent Behavioral Change.

\section{Research Validity and Reliability}

For the purpose to confirm validity and reliability in qualitative study, the examination of trustworthiness is crucial. The validity of the study is always questioned that can be geared to 
different issues (Golafshani, 2003) such as credibility, dependability, transferability, and conformability, which all together are called trustworthiness problems (Yilmaz, 2013). The study aims to improve the validity and reliability of the existing study, trustworthiness has been ensured using different strategies such as member checking, self-checking, content-based evidence, throwback questioning, respondent validation, and data triangulation.

With regard to this study the data collected can be confirmed reliable through the following procedures used to collect data of the current research. The data is trustworthy as they have acknowledged the data sources. It means that these data are from original source of information that have been identified as selected participants from the ex-juvenile of Katsina reformatory Centre. There is a comprehensive established contrast case seeking out resemblances and changes crosswise accounts to ensure different viewpoints are represented perfectly. The present study, has managed to include rich and thick verbatim accounts of the informants " interpretation to backing the outcomes of the study. The present study considered the participants validation: contains inviting informants to make observation of the transcript interview and if the final themes and perceptions formed sufficiently replicate the phenomenon under investigation.

\section{Results}

\section{The Innovation Orientation Behaviors of Ex-juvenile Entrepreneurs}

The interviews focused on ex-juvenile entrepreneur's innovation orientation behaviors of the interviewee and the influence of innovation orientation behavior. The study found that exjuvenile entrepreneurs applied innovation into their entrepreneurial activities. The finding emerged from three themes these are: Experiences, New idea, Novelty and inventive processes, However, within the innovation orientation influence we construct five sub categories which described ex-juvenile entrepreneurs' delinquent behavioral change (Drugs addicts, Drugs peddlers, Gang star, School truancy and Pick pocketing). The innovation orientation usually showed that the interviewees partake Experiences, Novelty and inventive processes, and New idea. These behaviors made to assess ex-juvenile entrepreneur's innovation orientation behavior.

Therefore, ex-juvenile entrepreneurs need to apply innovation in their entrepreneurial activities. The interviewee perception about innovation are either Experiences, Novelty and inventive processes, and New idea. This behavior arose because participants feel innovation has positive influence on their entrepreneurial activities and their subsequent behavioral change. Nevertheless, their experiences and innovation orientation behaviors vary.

Theme 1: Experiences orientation: The Experience orientation was one of the themes emerged of ex juvenile entrepreneur's innovation orientation behaviors. This behavior rises when these individuals employed an experience into their entrepreneurial activities. The study finding reveled that ex-juvenile entrepreneurs has applied experiences in running and managing their businesses. This imply that innovation orientation behavior has a positive influence on exjuvenile businesses. On the backing the informants of this study revealed that: PP2 Previously pick pocketing explained that:

(PP2, M, 25, Trader) ".........Customer service, Yes, customer satisfaction I introduce into my business, I use to be friendly with my customers, due to this my business 
place become a joint where many people come and relax, as a result of the people attention, my sales increases, in a day I can sell more than two (2) bucket of groundnut. Therefore, my sales growth rapidly....." (IDI with a former drug user PP2, Fieldwork 2019.

The result revealed that, participant applied experience to create an avenue where customers feel relaxed as a joint but taking advantage of that avenue to sell more of his product. The avenue brings the attention of many customers towards his product which resulted to the higher return and performance of the business which also subsequently increases the profit of the business. Whereas, PP10 ex-pick pocketer on the process of the interviews described that:

(PP10, M, 18, Furniture) "....... Yes, I do produce new design and unique to the market so that customers eye will be on my products than competitor's product. I sales more than my competitors in the market and dealers use to ask product made by me..." (IDIs Recording, Fieldwork 2019).

The result discovered the used of creativity and experience to produced something unique that customer will be patronized in the market over the competitors' product these also enhances the business performance and profitability.

Theme 2: Novelty and Inventive Processes: The Novelty and inventive processes were one of the themes emerged of ex juvenile entrepreneur's innovation orientation behaviors. This behavior occurred when these individuals employed a Novelty and Inventive Processes into their entrepreneurial activities. It was found that ex-juvenile entrepreneurs have applied novelty and inventive processes in their businesses. This imply that novelty and inventive processes has a positive influence on ex-juvenile businesses. On the backing the informants of this study revealed that: Similar perception had with the former drug user in IDIs PP9 and PP1, they stated that; (PP9, M, 30, Vulcanizer) "....... I came up with new style of vulcanizing tubeless tire, it was imported from Germany though it is expensive but qualitative. The new methods ease my work it is time saving and faster than the traditional way of vulcanizing though many customers see it simple and faster. The new method impacts my business by sales increases......"

The finding shows that, the participant has the ability to source a needed raw material and also shows how the participant came up with new methods of vulcanizing which is different from the traditional methods of vulcanizing. Therefore, by going forwards there is novelty and inventive process of vulcanizing which have some advantages over the traditional method of vulcanizing in terms of time saving and efficiency.

(PP1, M, 29, Tinker) "...... realize high demand and patronize from the customers considering the price and quality of the local oven produced here locally comparing with foreign ones. Similarly, I came up with an idea of battery cooker, and watering container all recently. I came up with some new product or I can say improved old product to new design ones......"

The finding shows the introduction of the new product into the market into market to have advantages over the competitors also better price and quality compare to foreign product. In fact, the finding shows alternative to foreign expensive products, the finding also revealed a novelty of battery cooker, also improved existing product to different shape and design of the old ones. 
(PP6, M, Furniture) "......There are foreign furniture's Dubai Made that I use to imitate. I have a catalogue that contain many pictures of furniture's made from Dubai. Then, I imitate exactly the design and sample. So far, this is the innovation employed into this business and it is yielding a positive result because the sales increase dramatically. Therefore, innovation make impacts in terms of turn over which boost the business and business eventually influence my wellbeing......" (IDIs Recording, Fieldwork 2019).

The result revealed the adoption of existing product to a different context for the purpose of taking advantage in the market. Hence, this imply the application of novelty and inventive process by the participant which resulted to positive influence the performance and profitability of the business and subsequently influence ex-juvenile entrepreneur's security among the society.

Theme 3: New Ideas: The New idea orientation was one of the themes emerged as ex juvenile entrepreneur's innovation orientation behaviors. This behavior rises when these individuals employed an experience into their entrepreneurial activities. The study finding reveled that exjuvenile entrepreneurs has applied new idea in running and managing their businesses. This imply that new idea has a positive influence on ex-juvenile entrepreneurial activities. On the support the informants of this study revealed that: Participant PP7 and PP3 past truant student describe that:

(PP7, M, 28, Furniture) ".........Yes! The new idea employed into my business is customer need satisfaction. I use to convey the product to the customers location so, my customers are do not need worried about the inconveniences anywhere the vehicle stop. Applying this idea many customers are happy and patronizing my products......."

The finding revealed how the participant introduced into the business a way of customer satisfaction and pleasing customer by taking the sold product to the customer destination regardless of the cost of transportation but aimed to satisfy and come closer to the customers in order to capture loyalty of the customers, which give rise to business turnover also resulted to the customers satisfaction. Participant PP3 Ex-truant student in his statement during an in-depth interview articulate that:

(PP3, M, 23, Motorcycle rewire/Spare part seller) "......I introduced new idea into my business the idea is that, if customer wants to change a motorcycle battery, I use to buy the old one from him so that he pays balance as a replacement of the old one. I came up with this idea in order to make my customers satisfied. I sale the old batteries to somebody as a scrap. Due to this idea, I do sale in large quantity of batteries more than anybody around this market. The Business development and expansion transpired as a result of new idea...." (IDIs Recording, Fieldwork 2019).

The finding discovered how an idea of product replacement yield a positive result, increases sales and business performance also revealed how customers been satisfied with the idea. This imply that the new idea of product replacement by the participant resulted to both customers satisfaction and business owners. Correspondingly, the new idea introduced to sale the scrap old 
batteries also increases the turnover and profitability. Nevertheless, Participant PP5 Ex-drugs peddler in his assertion during an in-depth interview pronounce that:

(PP5, M, 28, Defeather) "....... The new idea is customer service. I do give a maximum satisfaction to my customers. I always maintain customer relation cordial and ensure that, customers go happily.

The result shows how customer satisfaction used to retain the loyalty of the customers, this imply the use of an idea to established a cordial relationship to make customer happy which at the end will make the customer happy and call back whenever the product and services is needed. Participant PP4 an Ex-Gang member during the interviews claim that:

PP4, M, 19, Selling Used Motor Spare part) “... The only idea recently employ is going outside the town and buy the stock, this really pay because it brings more profit compare to buy in the town........."

The finding revealed that, the participant introduces new idea on where to source cheaper, quality and needed stock which at end enhances and increase the business profitability due to the source of the stock. Therefore, this imply by the new idea the business performance is influenced.

\section{The Innovation Orientation Influence towards Ex-juvenile Entrepreneurs' Delinquent Behavioral Change.}

The finding on delinquent behavioral change emerged from five themes, these are: Abstained from drugs addicts, abstained from drugs peddling, desisted Pick-pocketing, quieting from Gang stars activities and stopped School truancy. The finding from the study revealed that ex-juvenile entrepreneurs abstained from different delinquent behaviors due to their orientation. This imply that innovation orientation has positive influence towards ex-juvenile entrepreneurs' delinquent behavioral change.

Abstained Drugs Addicts: Abstained from drugs addict: was one of the themes of ex juvenile delinquent behavioral change. This behavior rises when these individuals abstained from drugs addict. The study found that ex-juvenile entrepreneurs abstained from drugs addicts which imply that they withdrawal from the illicit drugs habit due to their business commitment. On the support the informants of the study duo describe that:

(PP8, M, 28, Metal work) ".... I stopped drugs addicts and now always busy in my shop thinking of how to convince and retained my customers..." (PP1, M, 29, Furniture) ".......I was a drug user and addicted to the highest level but, presently, due to my innovativeness orientation behaviour, I gate ride of drugs addict, and not associating myself with delinquent friends, currently, fully concentrated to business innovation...." (IDIs Recording Fieldwork, 2019).

The finding discovered that being committed into innovativeness entrepreneurial orientation activities resulted to drugs addict withdrawal, conferring the finding revealed how being innovatively busy limit the chances of drugs behavior as the drugs user will have no chance of taking drugs rather thinking how to think innovatively.

Stopped Drugs Peddlers: Abstained from drugs peddling: was one of the themes of ex juvenile delinquent behavioral change This behavior rises when these individuals abstained from drugs addict. The study found that ex-juvenile entrepreneurs abstained from drugs peddling which 
imply that they desist from the illegal drugs peddling due to engagement into entrepreneurial activities. On the support the informants of the study duo describe that:

(PP5, M, 28, Defeather) ".... Presently not involve in drugs business, I abstained from using drugs, I have an alternative source of income...." (PP2, M, 25, Trader) "...I stopped drugs peddling, I abstained from all delinquent behaviours and disassociated myself from delinquents' friends, my concerns now are how to improve my business and give maximum satisfaction to my customers...." (IDIs Recording Fieldwork, 2019).

The outcome exposed how the participant quit a drug peddling due to available alternative, this imply that with other option an ex-juvenile can transform totally also, it is imply that delinquents' behaviors is associated with lack of opportunity and associating with delinquent friends. This suggest that ex-juvenile entrepreneurial innovation orientation behaviors influence delinquent behavioral change.

School Truancy: School truancy was another more theme of ex-juvenile delinquent behavioral change This behavior escalated when these individuals change from school truancy. The study finding revealed that ex-juvenile entrepreneur's behavior changes from school truancy to entrepreneurial activities. This imply that ex-juvenile entrepreneur's truancy behavior changes due to their business obligation. So, on the support the informants of the study views that:

(PP7, $M, 25$, Engine Oil Seller) “...am no longer a truant student since engaged into legal business activities (Selling of Engine Oil and Petroleum business) I engaged into business activities and this led to the walkout from truancy so, am no longer in truancy, am now a businessman..." (PP3, $M, 23$, Petroleum Seller)"...... was detained in reformatory centre due to the school truancy but now finished school and doing this business. therefore, no more school truancy am an entrepreneur now not student..." (IDIs Recording Fieldwork, 2019).

The result exposed that entrepreneurial innovation orientation behaviors influence truant student to change their truancy behaviors, this implied that not all kids need to be in the school to the university level some are better off in the market, some are better off in the workshops and some even in the sports, therefore, the study suggest that, entrepreneurial innovation orientation behaviors influence ex-juvenile entrepreneurs school truancy behaviors.

Gang Activities: Gang Stars or gang activities, was another theme of ex-juvenile delinquent behavioral change This behavior arises when these individuals stopped school truancy. The study finding discovered that ex-juvenile entrepreneur's gang activities behavior changes due to their entrepreneurial activities. This imply that ex-juvenile entrepreneur's gang activities behavior changes due to their business commitments. Accordingly, this means that autonomous orientation positively influenced ex-juvenile gang activities behavior. On the support the informants of the study views that: 
INTERNATIONAL JOURNAL OF ACADEMIC RESEARCH IN BUSINESS AND SOCIAL SCIENCES

Vol. 10, No. 6, June, 2020, E-ISSN: 2222-6990 @ 2020 HRMARS

(PP9, M, 28, Vulcanizer) "....resulting to vulcanizing and selling of tire I quit of gang activities, am now focus and fully concentrating on my vulcanizing business..." (PP4, M, 19, Vulcanizer) "....I quit gang activities and also disconnect myself from gang members am now always in my place of work...." (IDls Recording Fieldwork, 2019).

The result interpretation that, delinquent behavioral change occurred as a result of being in certain business as the participant concentrate to the business. Therefore, being business innovative oriented can change schedule and activities engaged by the participants. This imply that business innovation can influence ex-juvenile Gang activities behaviors to business innovation.

Pick-pocketers: Pick-pocketing was another theme of ex-juvenile delinquent behavioral change This behavior arises when these individuals stopped Pick-pocketing. The study finding discovered that exjuvenile entrepreneur's Pick-pocketing behavior changes due to their entrepreneurial activities. This imply that ex-juvenile entrepreneur's pick-pocketing behavior changes due to their business commitments. Accordingly, this means that autonomous orientation positively influenced ex-juvenile Pick-pocketing behavior. On the support the informants of the study opined that:

(PP10, M, 18, Furniture) “.... I was a pick-pocketing, but now, no longer partaking in pick-pocketing presently busy to improve my business to the modern one. (PP6, M, 29, Furniture), "...Am an entrepreneur at the moment being busy with customers, forced got ride out of drugs because I am in the workshop always; I distance myself from antisocial friends but creating something value and new into my business...." (IDIs Recording Fieldwork, 2019).

The result discovered that being a modern entrepreneur, creating something new into the business, and disengaging from disruptive friends resulting to quietening from pick-pocketing delinquent behaviour. This imply that entrepreneurial innovativeness behaviour influences ex-juvenile pickpocketing behaviours.

\section{Discussion and Conclusion}

The research proposition required to determine if entrepreneurial orientation (EO): innovation dimension influence ex-juvenile entrepreneurial activities and their delinquent behavioral change. The study finding reveled that ex-juvenile entrepreneurs has applied experiences in running and managing their businesses. It was also found that, ex-juvenile entrepreneurs have applied new idea in their businesses. Similarly. it was found that ex-juvenile entrepreneurs have applied novelty and inventive processes in their businesses.

Therefore, the study found that ex-juvenile entrepreneurs employ innovation behaviors into their entrepreneurial activities which shows a positive influence towards their entrepreneurial activities. This is consistent with EO theory (Lumpkin \& Dess, 1996; Wiklund \& Shepherd, 2005). This also confirm previous empirical studies (Boohene et al., 2012; Fatoki, 2014; Matchaba-Hove \& Vambe, 2014; Buli, 2017). However, on the innovation orientation influence towards ex-juvenile entrepreneurs delinquent behavioral change; the study finding revealed that, ex-juvenile entrepreneurs stopped drug peddling, drugs addict, pick-pocketing, school truancy and gang activities due to their engagement into entrepreneurial activities, which implied ex-juvenile entrepreneurs delinquent behavioral change due to the autonomous orientation influenced. The finding is affirmed with the SCT theory (Bandura, 1986, Bandura 1977). This also consistent with previous empirical studies (Downing 2012; Soloman, 2012; Sonfield, 2013; Cai, et al., 2019). 


\section{Conclusion}

In conclusion, we conclude that, entrepreneurial innovativeness orientation has a positive influence towards ex-juvenile entrepreneurial activities and subsequent ex-juvenile entrepreneurs delinquent behavioral change. Entrepreneurial innovativeness orientation literatures are conversant of innovation dimensions on firms' performance but not much well-informed about the influence of innovation orientation on delinquent behavioral change among ex-juvenile entrepreneurs. The finding of the study revealed that Ex-juvenile entrepreneurs applied innovation orientation in their entrepreneurial activities and we found that innovation orientation influence ex-juvenile entrepreneurial activities as well as their previous delinquent behavioral change.

Research Contribution: we contribute to the EO theory in the sense that EO not only influence to firm's performance and profitability but also individual EO influences delinquent behavioral change. Our study makes a new contribution as the first research to study innovativeness orientation behaviors towards delinquent behavioral change particularly ex-juvenile entrepreneurs in Katsina state, Nigeria and so, we provide renewed empirical evidence on ex-juvenile entrepreneurs for the expansion of the literature. We also extent the literature on individual EO innovation dimension which mostly comes from EO of firms. Once more, we make fresh contributions to the body of knowledge based on the evidence that, the influence of innovativeness orientation behaviors on exjuvenile entrepreneurs by indicating that: (i) innovativeness orientation behaviors influence exjuvenile entrepreneurial activities success in Katsina state, Nigeria (ii) innovativeness orientation behaviors influence towards ex-juvenile entrepreneur's delinquent behavioral change in Katsina state, Nigeria. This imply that, the application of discoveries is appropriate to ex-juvenile if entrepreneurs maximize profit based on entrepreneurial activities in Katsina state, Nigeria who believed that entrepreneurial activities as necessity-based and an alternative context to better improve business performance and subsequent delinquent behavioral change than theory application.

The study also has empirically contributed a fresh knowledge about the EO, innovation orientation disclosing that EO has positive influence on the delinquents' behavioral change. Accordingly, this study has essentially proved the unclear of knowledge by providing that empirical evidence around the fresh knowledge about ex-juvenile entrepreneurs. Contributing also our understanding of EO innovation dimensions that relate to ex-juvenile entrepreneurs of retail enterprises in the context of entrepreneurship segment in Katsina state, Nigeria. The study also contributes to the theory as the first to explore the ex-juvenile entrepreneur's innovation orientation influence towards delinquent behavioral change.

The Practical Implications: practical implications for policy makers. First, it suggests that governments should develop entrepreneurship orientation innovation capacity programs at individual level and orientation more specifically on juvenile at correctional centers by creating a formal entrepreneurship framework, entrepreneurship capacity building, and curriculum which enables access of entrepreneurship skills. Secondly, this support would be more effective if started right from the reformatory center and make sure of proper follow-up upon release from the reformatory center then, some basic knowledge of entrepreneurship which they could obtain at earlier stages of rehabilitations. Lastly, policy makers should mandate financial institutions to 
INTERNATIONAL JOURNAL OF ACADEMIC RESEARCH IN BUSINESS AND SOCIAL SCIENCES

Vol. 10, No. 6, June, 2020, E-ISSN: 2222-6990 @ 2020 HRMARS

consider entrepreneurial orientation autonomous capacity of ex-juvenile entrepreneurs in their credit assessment not only collateral capacity.

The Limitation: limitation is that, Participants of the study were drawn from ex-juvenile entrepreneurs of only one State from thirty-six Sates of Nigeria. This presented rather a limited scope of the study and limited generalizability as it was based on ex-juvenile from single Reformatory center in Katsina State, Nigeria. Accordingly, further research work is required to increase the population size by taking cognizance of additional states to cover the whole Northern, Nigeria. Also, can consider quantitative methods study about the phenomenon for more generalization.

\section{References}

Andersen, E. S. (2010). “Rethinking Project Management. An Organizational Perspective”. Strategic Direction.

Arshad, A. S., Rasli, A., Arshad, A. A., and Zain, Z. M. (2014), "The Impact of Entrepreneurial Orientation on Business Performance: A Study of Technology-based SMEs in Malaysia", Procedia - Social and Behavioral Sciences, Vol. 130, pp. 46-53.

Bolton, D. L., \& Lane, M. D. (2012). Individual Entrepreneurial Orientation: Development of a Measurement Instrument. Education+ Training.

Boohene, R., Marfo-Yiadom, E., \& Yeboah, M. A. (2012). An Empirical Analysis of the Effect of Entrepreneurial Orientation on Firm Performance of Auto Artisans in the Cape Coast Metropolis, Developing Country Studies, 2(9), 77-86.

Boyatzis, R. E. (1998; pp 63). Transforming qualitative information: Thematic analysis and code development. sage.

Buli, B. M. (2017), "Entrepreneurial Orientation, Market Orientation and Performance of SMEs in the Manufacturing Industry: Evidence from Ethiopian Enterprises", Management Research Review, Vol. 40 No. 3, pp. 292-309.

Casillas, J. C., Moreno, A. M., \& Barbero, J. L. (2010). A Configurational Approach of the Relationship between Entrepreneurial Orientation and Growth of Family Firms. Family Business Review, 23(1), 27-44.

Debicki, B. J., Kellermanns, F. W., Chrisman, J. J., Pearson, A. W., \& Spencer, B. A. (2016). Development of a Socioemotional wealth Importance (SEWi) Scale for Family Firm Research. Journal of Family Business Strategy, 7(1), 47-57.

Denzin, N. K. (1989). The Research act: A Theoretical Introduction to Sociological Methods (3rd ed.). Englewood Cliffs, NJ: Prentice Hall. 1989

Dess, G. G., \& Lumpkin, G. T. (2005). The Role of Entrepreneurial Orientation in Stimulating Effective Corporate Entrepreneurship. Academy of Management Perspectives, 19(1), 147-156.

Dess, G. G., and Lumpkin, G. T. (2005), "The role of Entrepreneurial Orientation in Stimulating Effective Corporate Entrepreneurship", Academy of Management Perspectives, Vol. 19 No. 1, pp. 147-156.

Dickson, P. H., \& Weaver, K. M. (2008). The Role of the Institutional Environment in Determining Firm Orientations Towards Entrepreneurial Behavior. International Entrepreneurship and Management Journal, 4(4), 467-483. 
INTERNATIONAL JOURNAL OF ACADEMIC RESEARCH IN BUSINESS AND SOCIAL SCIENCES

Vol. 10, No. 6, June, 2020, E-ISSN: 2222-6990 @ 2020 HRMARS

Downing, C. (2012). Bolivian Prison Entrepreneurship: An Unexpectedly Successful Rehabilitation Method. Journal of Enterprising Communities: People and Places in the Global Economy, 6(4), 339-349.

Draper, J. (2004) The Relationship Between Research Question and Research Design. In: Crookes, Patrick and Davies, Sue eds. Research into Practice: Essential Skills for Reading and Applying Research in Nursing and Health Care. Edinburgh: Bailliere Tindall, pp. 69-84.

Fatoki, O. (2014). The Entrepreneurial Orientation of Micro Enterprises in the Retail Sector in South Africa, J Sociology Soc Anth, 5(2), 125-129.

Francis, J. J., Johnston, M., Robertson, C., Glidewell, L., Entwhistle, V., Eccles, M. P., Grimshaw, J. M. (2010): What is an Adequate Sample size? Operationalizing Data Saturation for Theory-Driven Interview Studies. Psychol. Health 25(10), 1229-1245.

Fugard, A. J., \& Potts, H. W. (2015). Supporting Thinking on Sample Sizes for Thematic Analyses: A Quantitative Tool. International Journal of Social Research Methodology, 18(6), 669-684.

Given, L. M. (2016): 100 Questions (and Answers) About Qualitative Research. Sage, Thousand Oaks. Goktan, A. B., and Gupta, V. K. (2015), "Sex, Gender, and Individual Entrepreneurial Orientation: Evidence from Four Countries", The International Entrepreneurship and Management Journal, Vol. 11 No. 1, pp. 95-112.

Golafshani, N. (2003). Understanding Reliability and Validity in Qualitative Research. The Qualitative Report, 8(4), 597-606.

Guest, G., Bunce, A., and Johnson, L. (2006), "How Many Interviews are Enough? An Experiment with Data Saturation and Variability", Family Health International, Vol.18 No.1, pp.59-82,

Hameed, I. (2011). Impact of Entrepreneurial Orientation, Entrepreneurial Management and Environmental Dynamism on Firm's Financial Performance. Journal of Economics and Behavioral Studies, 3(2), 101-114.

Hughes, M., \& Morgan, R. E. (2007). Deconstructing the Relationship Between Entrepreneurial Orientation and Business Performance at the Embryonic Stage of Firm Growth. Industrial Marketing Management, 36(5), 651-661.

Jiang, X., Yang, Y., Pei, Y. L., and Wang, G. (2016), "Entrepreneurial Orientation, Strategic Alliances, and Firm Performance: inside the black box", Long "Range Planning, Vol. 49 No. 1, pp. 103116.

Klofsten, M., Fayolle, A., Guerrero, M., Mian, S., Urbano, D., \& Wright, M. (2019). The Entrepreneurial University as Driver for Economic Growth and Social Change-Key Strategic Challenges. Technological Forecasting and Social Change, 141, 149-158.

Kollmann, T., \& Stöckmann, C. (2014). Filling the Entrepreneurial Orientation-Performance Gap: The Mediating Effects of Exploratory and Exploitative Innovations. Entrepreneurship Theory and Practice, 38(5), 1001-1026.

Krauss, S. I., Frese, M., Friedrich, C., \& Unger, J. U. (2005). Entrepreneurial Orientation: A Psychological Model of Success Among Southern African Small Business Owners. European Journal of Work and Organizational Psychology, 14, 315-344.

Lechner, C., and Gudmundsson, S. V. (2014), "Entrepreneurial Orientation, Firm Strategy and Small Firm Performance", International Small Business Journal, Vol. 32 No. 1, pp. 36-60.

Loh, W. Y. (2011). Classification and regression trees. Wiley Interdisciplinary Reviews: Data Mining and Knowledge Discovery, 1(1), 14-23. 
INTERNATIONAL JOURNAL OF ACADEMIC RESEARCH IN BUSINESS AND SOCIAL SCIENCES

Vol. 10, No. 6, June, 2020, E-ISSN: 2222-6990 @ 2020 HRMARS

Lukes, M., \& Laguna, M. (eds.) (2010). Entrepreneurship: A psychological approach. Prague: O economica.

Lumpkin, G. T., Cogliser, C. C., \& Schneider, D. R. (2009). Understanding and Measuring Autonomy: An Entrepreneurial Orientation Perspective. Entrepreneurship Theory and Practice, 33(1): 4769.

Lumpkin, G. T., and Gregory, G. D. (1996), 'Clarifying the Entrepreneurial Orientation Construct and Linking it to Performance', Academy of Management Review 21 (1), 135-172.

Malterud, K., Siersma, V. D., and Guassora, A. D. (2015), "Sample Size in Qualitative Interview Studies: Guided by Information Power", Qualitative Health Research, pp. 1-8.

Matchaba-Hove, T. M., \& Vambe, A. K. (2014). Entrepreneurial Orientation and Performance of Small Businesses in the Retail Sector in the Eastern Cape Province of South Africa, Journal of Marketing and Management, 5 (2), 12-39.

McCluskey, T., Broderick, A., Boyle, A., Burton, B., and Power, D. (2010), "Evidence on Irish Financial Analysts' and Fund Managers' Views About Dividends", Qualitative Research in Financial Markets, Vol. 2 No. 2, pp. 80-99.

Miller, D. (2011). Miller (1983) Revisited: A Reflection on EO Research and some Suggestions for the future. Entrepreneurship Theory and Practice, 35(5), 873-894.

Mohamad, S. G. B., and Perry, C. (2015), "How Fund Managers in Malaysia Make Decisions", Qualitative Research in Financial Markets, Vol. 7 No. 1, pp. 72-87.

Munene, J. C., Schwartz, S. H., and Kibanja, G. M. (2005), Escaping from Behavioral Poverty in Uganda: The Role of Culture and Social Capital, Fountain Publishers, Kampala.

Muthee-Mwangi, M. M. A., \& Ngugi, K. (2014). Influence of Entrepreneurial Orientation on Growth of Micro and Small Enterprises in Kerugoya, Kenya, European Journal of Business Management, 1 (11), 417-438.

Orobia, L. A., Byabashaija, W., Munene, J. C., Sejjaaka, S. K., and Musinguzi, D. (2013), "How do Small Business Owners Manage Working Capital in an Emerging Economy? A Qualitative Inquiry", Qualitative Research in Accounting \& Management, Vol. 10 No. 2, pp. 127-143.

Qu, S. Q., and Dumay, J. (2011), "The Qualitative Research Interview”, Qualitative Research in Accounting \& Management, Vol. 8 No. 3, pp. 238-264.

Reynolds, P., Bygrave, W., Autio, E., Cox, L., and Hay, M. (2002), Global Entrepreneurship Monitor: 2002 Executive Report, Ewing Marion Kauffman Foundation, Wellesley, MA.

Runyan, R., Droge, C., \& Swinney, J. (2008). Entrepreneurial orientation versus small business orientation: what are their relationships to firm performance? Journal of Small Business Management, 46(4), 567-588.Saunders, B., Sim, J., Kingstone, T., Baker, S., Waterfield, J., Bartlam, B., ... \& Jinks, C. (2018). Saturation in Qualitative Research: Exploring its Conceptualization and Operationalization. Quality \& Quantity, 52(4), 1893-1907.

Schumpeter, J. A. (1934). The Entrepreneurship Orientation of Economic Development. Public Opinion Quarterly, 58(4), 358-480.

Solomon, A. L. (2012). In Search of a Job: Criminal Records as Barriers to Employment. NIJ Journal, 270, 42-51.

Sonfield, M. (2013). Entrepreneurship Training and Prisoner Re-Entry: Lessons from a Successful Program. Small Business Institute, 91.

Sonfield, M. C. (2008). Entrepreneurship and Prisoner Re-entry: The Development of a Concept. Small Business Institute Research Review, 35. 
INTERNATIONAL JOURNAL OF ACADEMIC RESEARCH IN BUSINESS AND SOCIAL SCIENCES

Vol. 10, No. 6, June, 2020, E-ISSN: 2222-6990 @ 2020 HRMARS

Sonfield, M., Lussier, R., \& Barbato, R. (2001). The Entrepreneurial Aptitude of Prison Inmates and the Potential Benefit of Self-employment Training Program. Academy of Entrepreneurship Journal, 7(2), 85-94.

Sorescu, A. B., Chandy, R. K., \& Prabhu, J. C. (2003). Sources and Financial Consequences of Radical Innovation: Insights from Pharmaceuticals. Journal of Marketing, 67(4), 82-102.

Strauss, A., \& Corbin, J. M. (1990). Basics of Qualitative Research: Grounded Theory Procedures and Techniques. Journal of Qualitative Sociology, 1(13), 3-21.

Terziovski, M. (2010). Innovation Practice and its Performance Implications in Small and Medium Enterprises (SMEs) in the Manufacturing Sector: A Resource-based View. Strategic Management Journal, 31(8), 892-902.

Tijjani, B., Fifield, S. G. M. and Power, D. M. (2009), "The Appraisal of Equity Investments by Nigerian Investors", Qualitative Research in Financial Markets, Vol. 1 No. 1, pp. 6-26,

Ukpabio, M., \& Siyanbola, W. O. (2017). Technological Innovation and Performance of Manufacturing Firms in Nigeria. International Journal of Innovative Research and Advanced Studies, 4(11), 1019.

Wales, W. J. (2016). Entrepreneurial Orientation: A Review and Synthesis of Promising Research Directions. International Small Business Journal, 34(1), 3-15.

Wang, C. H., Chen, K. Y., and Chen, S. C. (2012), "Total Quality Management, Market Orientation and Hotel Performance: The Moderating Effects of External Environmental Factors", International Journal of Hospitality Management, Vol. 31 No. 1, pp. 119-129.

Wiklund, J. (1999). The sustainability of the entrepreneurial orientation-performance relationship. Entrepreneurship theory and practice, 24(1), 37-48.

Wiklund, J., Shepherd, D. (2005), Entrepreneurial Orientation and Small Business Performance: A Configurational Approach. Journal of Business Venturing, 20(1), 71-91.

Wiklund, J., and Shepherd, D. (2003), "Knowledge-based Resources, Entrepreneurial Orientation, and the Performance of Small and Medium-sized Businesses", Strategic Management Journal, Vol. 24 No. 13, pp. 1307-1314.

Usman, B., \& Hashim, S. bn. (2020). Autonomous Orientation and Delinquent Behavioral Change: A Case Study of Ex-Juvenile Entrepreneurs in Katsina State, Nigeria. International Journal of Academic Research in Business and Social Sciences, 10(6), 164-183.

Witt, U. (2016). How evolutionary is Schumpeter's theory of economic development? In Rethinking Economic Evolution. Edward Elgar Publishing.

Yilmaz, S., \& Venugopal, V. (2013). Local Government Discretion and Accountability in Philippines. Journal of International Development, 25(2), 227-250.

Yin, R. K. (2015). Qualitative research from start to finish. Guilford publications.

Zulkifli, R. M., \& Rosli, M. M. (2012). Entrepreneurial Orientation and Business Success of Malay Entrepreneurs: Religiosity as Moderator, International Journal of Humanities and Social Science, 2(10), 264-275. 
INTERNATIONAL JOURNAL OF ACADEMIC RESEARCH IN BUSINESS AND SOCIAL SCIENCES

Vol. 10, No. 6, June, 2020, E-ISSN: 2222-6990 @ 2020 HRMARS

\section{APPENDIX}

Appendix 1: Participants Demographic Data

\begin{tabular}{|c|c|c|c|c|c|c|}
\hline \multicolumn{7}{|c|}{ Participants Demographic Data } \\
\hline Participants & Age & $\begin{array}{c}\text { Delinquent } \\
\text { Behaviours } \\
\text { Records }\end{array}$ & $\begin{array}{c}\text { Entrepreneurial } \\
\text { Activities Engaged }\end{array}$ & $\begin{array}{c}\text { Skills } \\
\text { Obtained }\end{array}$ & Education & $\begin{array}{c}\text { Annual Income } \\
\text { NGN N }\end{array}$ \\
\hline PP1 & 28 & Drugs addict & $\begin{array}{l}\text { Selling of Kitchen } \\
\text { Utensil }\end{array}$ & $\begin{array}{l}\text { Metal } \\
\text { work }\end{array}$ & SSS & $\begin{array}{l}400,000- \\
800,000\end{array}$ \\
\hline PP2 & 25 & Pick-pocketer & Trader & Tailoring & SSS & $\begin{array}{r}000,- \\
200,000\end{array}$ \\
\hline PP3 & 23 & $\begin{array}{l}\text { Truant } \\
\text { Student }\end{array}$ & $\begin{array}{l}\text { Selling of Motorcycle } \\
\text { Spare Parts }\end{array}$ & $\begin{array}{l}\text { Metal } \\
\text { work }\end{array}$ & JSS & $\begin{array}{l}800,000-1, \\
800,000\end{array}$ \\
\hline PP4 & 19 & $\begin{array}{l}\text { Gang } \\
\text { Member }\end{array}$ & $\begin{array}{l}\text { Selling of Used Car } \\
\text { Spare Parts }\end{array}$ & $\begin{array}{l}\text { Metal } \\
\text { work }\end{array}$ & JSS & $\begin{array}{l}400,000- \\
800,000\end{array}$ \\
\hline PP5 & 28 & Drug Peddler & $\begin{array}{l}\text { Defeather and Selling } \\
\text { of Chicken }\end{array}$ & Carpentry & JSS & $\begin{array}{l}400,000- \\
800,000\end{array}$ \\
\hline PP6 & 29 & $\begin{array}{l}\text { Drugs } \\
\text { Peddler }\end{array}$ & $\begin{array}{l}\text { Carpentry and Selling } \\
\text { of Furniture }\end{array}$ & Carpentry & SSS & $\begin{array}{l}200,000- \\
400,000\end{array}$ \\
\hline PP7 & 28 & $\begin{array}{l}\text { Truant } \\
\text { Student }\end{array}$ & Selling of Engine Oil & Carpentry & NCE & $\begin{array}{l}200,000- \\
400,000\end{array}$ \\
\hline PP8 & 26 & Drugs Addict & $\begin{array}{l}\text { Welder and Selling } \\
\text { Doors }\end{array}$ & $\begin{array}{l}\text { Metal } \\
\text { work }\end{array}$ & FLC & $\begin{array}{l}200,000- \\
400,000\end{array}$ \\
\hline PP9 & 30 & Gang Stars & $\begin{array}{l}\text { Vulcaniser and Selling } \\
\text { of tires }\end{array}$ & $\begin{array}{l}\text { Metal } \\
\text { work }\end{array}$ & SSS & $\begin{array}{l}400,000- \\
800,000\end{array}$ \\
\hline PP10 & 18 & Pick-pocketer & $\begin{array}{l}\text { Carpentry and Selling } \\
\text { Furniture }\end{array}$ & Carpentry & FLC & $000-200,000$ \\
\hline
\end{tabular}

